\title{
ALK positive diffuse large B-cell lymphoma, lymphoplasmablastic differentiation
}

Dlal Nemenqani, Enaam Junainah*, Saeed Al-Amoudi, Jamal Junainah, Amany Mamdouh, Huda Bajunaid and Abdulelah Saber

*Correspondence: mennastar3@hotmail.com

Departments of Pathology, King Abdulazis Specialist Hospital, Taief, Saudi Arabia.

\begin{abstract}
We report detailed clinical and pathologic features of cases of anaplastic lymphoma kinase-positive diffuse large B-cell lymphoma (ALK-DLBCL), a rare entity with only 33 currently reported cases. This reported case. Biopsies from adult male patients aged, 44 years (three lymph nodes And one skin lesion) the lymph node exhibited immunoblastic/plasmablastic morphology. By immunohistochemistry and they expressed cytoplasmic ALK-1, CD138, VS38 (3/3), monoclonal cytoplasmic light Chain, CD45, CD19, CD79 and were negative for CD3, CD30, CD20 and EMA. Showed rare CD43 (.) reactivity.
\end{abstract}

Keywords: ALK positive, difuuse large B-cell lymphoma, lymphoplasmoblastic pattern, anaplastic lymphoma

\section{Introduction}

A 44 years old male patient initially presented to King Abdulaziz Specialist hospitall, Taif with Bronchopneumonia of the middle lung zone) \& renal impairment. Sputum analysis showed gram positive (+ve) cocci and gram negative (-ve) bacilli with no AFB. Two months later, patient presented to KAASH with hoarseness of voice and mild dysphagia. Clinical examination showed left vocal cord paralysis. Ct scan neck showed left pyriform lesion with cervical lymphadenopathy. Bronchoscopy, esophagoscopy, and laryngoscopic biopsy were performed. Histopathology showed non-specific infection with no malignancy. A month later, patient presented with disseminated herpes zoster. Patient given. Acyclovir for 5 days and referred to Oncology Surgeon. Clinical examination showed a right outer canthus deep ulcer and wound, generalized lymphadenopathy (cervical, axilla and inguinal). Left thigh ulcerated lesion was also present. Patient was tested for HIV, II, P24 Ag in serum HCV, HBV all are negative. Again total protein in serum was high $(13 \mathrm{gm} / \mathrm{dl})$ while serum albumin is low $(2 \mathrm{gm} / \mathrm{dl})$. Excision biopsy of right cervical lymph node together with biopsies from right outer canthus ulcer and left thigh lesion were performed. The lymph node showed high grade ALK +ve large B-cell lymphoma with plasmablastic differentiation, skin biopsies from right canthus and left thigh showed chronic non-specific infections. Ct chest and abdomen showed nodular lung lesions involving both lungs, hepato-splenomegaly, para-aortic and Mesenteric lymph node enlargement. Patient gives history of fever and weighs loss. A staging bone marrow showed low level involvement by chronic lymphocytic leukemia, but no evidence of large cell lymphoma. The patient received $\mathrm{CHOP}$ and neck Irradiation for stage IV disease. Patient currently alive.

\section{Results}

\section{Immunohistochemical result}

Punnel of immuno stain are preformed showing the atypical Lymphoid cell are positive for B cell marker CD79 (Figure 1) and CD19. About 30\% of the cells are positive for CD 43 and CD4. Plasma cell marker show $40 \%$ positivity with CD 138 (Figure 2) as well as VS38 (3/3). Kappa and Lamda show restriction with $100 \%$ positivity with Lamda stain. ALK antibody show strong granular cytoplasmic positivity (Figure 3). K167 is > than $80 \%$ EBV is strong positive (Figure 4). White negative result are observed with Cd20, BCL6, CD10, CD3, Cyclinc D, CD23, EMA, and CD30 (Figure 5).

\section{Histological examination of the lymph node}

The lymphoid tissue showing partial effaced architecture with vague nodular pattern accompanied by sclerosis and star sky appearance. The neoplastic infiltrate is composed of intermediate nuclei, prominent multiple nucleoli and abundant amorphelic cytoplasm, with focal area showing plasmocytoid differentiation (Figure 6). Frequent Mitotic figures are seen.

\section{FISH for ALK gene rearrangement}

FISH demonstrated an ALK gene rearrangement (Figure 7). Demonstrates a clearly separated. Orange and green signal indicating rearrangement of the ALK gene, (arrow) the normal ALK gene signal is seen as overlapping/fusion of the orange And green signals (yellow). As the ALK probe is a break Apart probe.

\section{Disscusion}

We report A cases of plasmablastic lymphoma kinase positive diffuse large B-cell lymphoma (ALK-DLBCL) based on 
Nemenqani et al. Pathology Discovery 2013,

http://www.hoajonline.com/journals/pdf/2052-7896-1-8.pdf

doi: $10.7243 / 2052-7896-1-8$

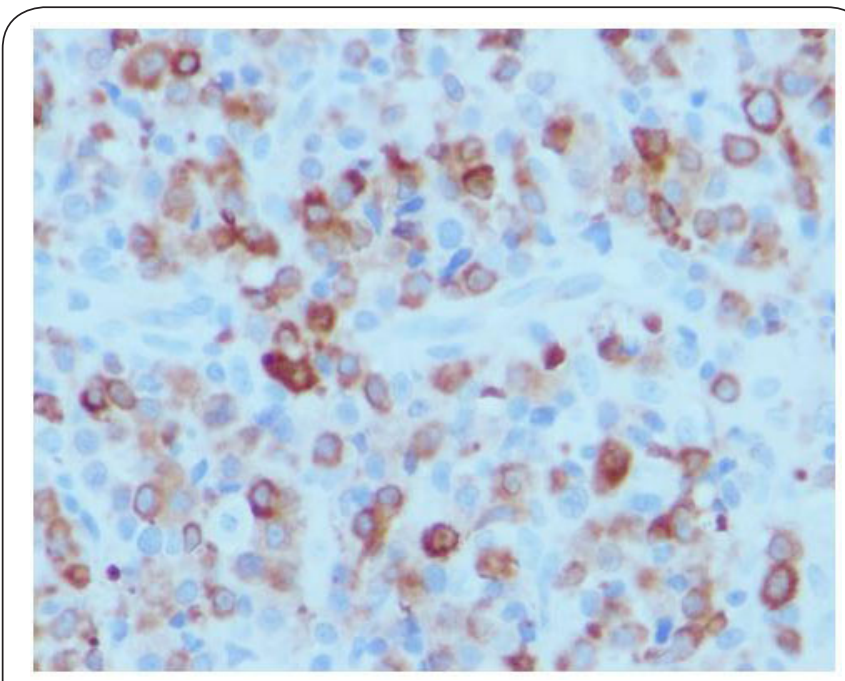

Figure 1. High power examination, original magnifcation $\mathrm{x} 40$. CD79, with a moderate and focal membrane pattern.

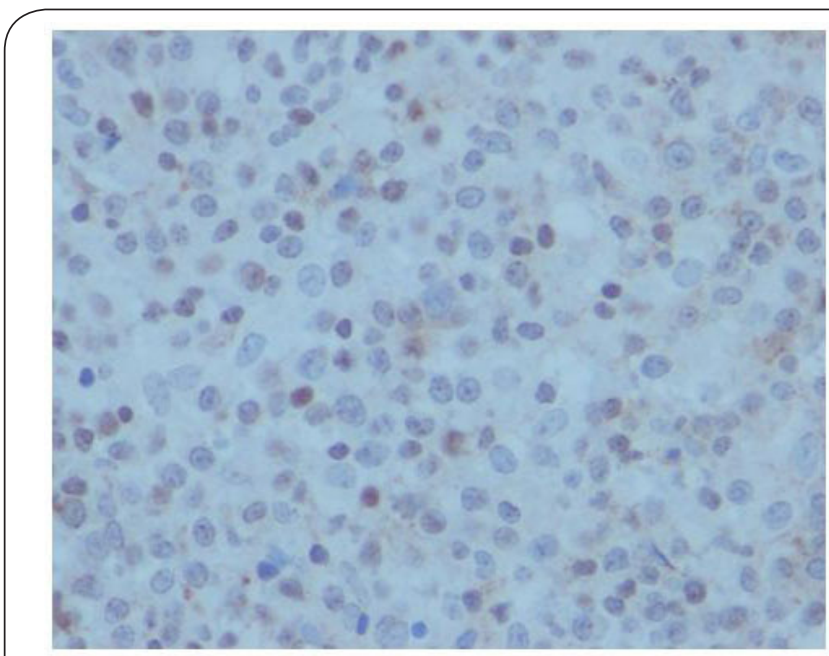

Figure 2. High power examination, original magnifcation $\mathrm{x} 40$. CD138, with week and focal nuclear and cytoplasmic pattern.

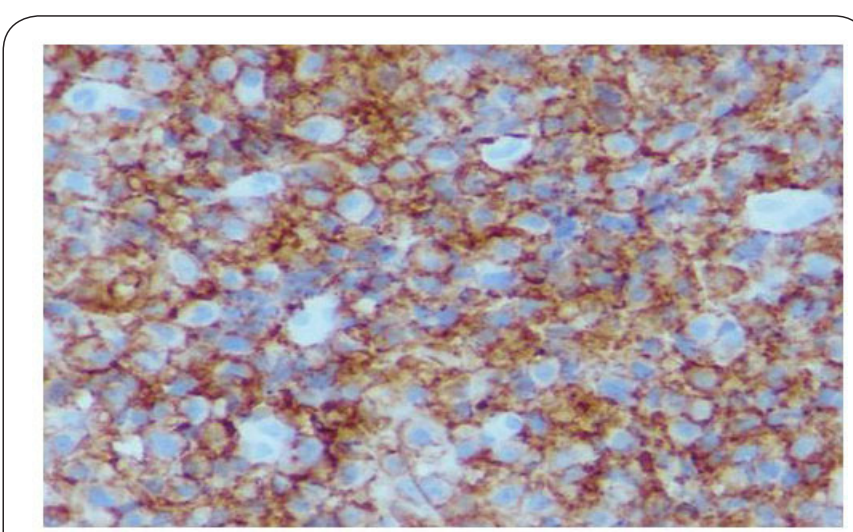

Figure 3. High power examination, original magnifcation $x 40$. The cells are strongly expresses ALK, with a diffuse cytoplasmic and nuclear pattern.

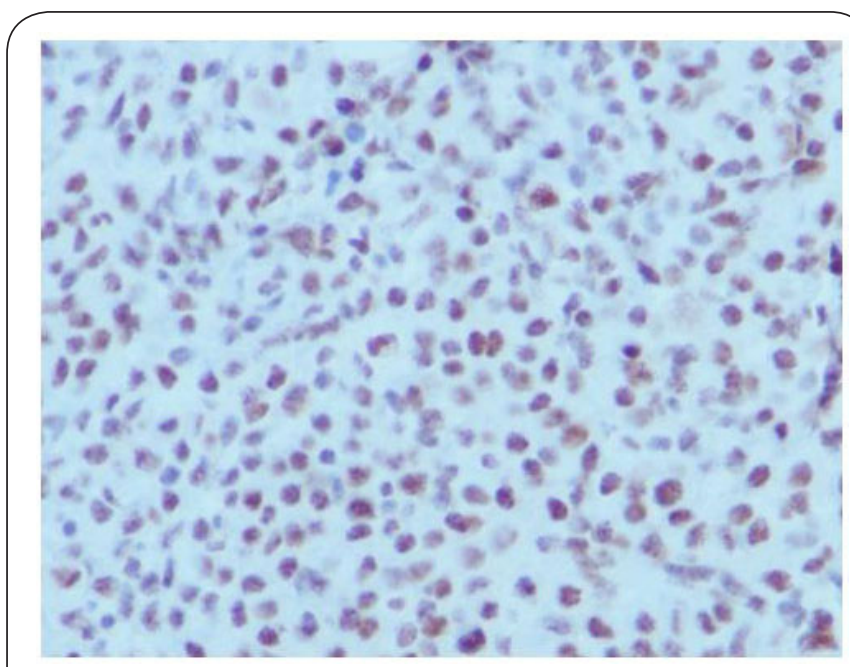

Figure 4. High power examination, original magnifcation $\mathrm{x} 40$. The tumor show focal strong nuclear stain with EBV stain.

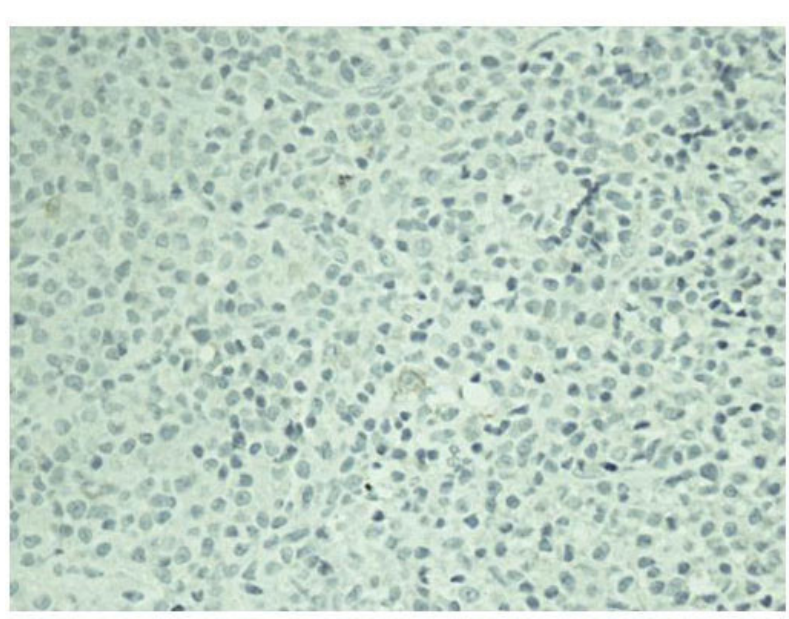

Figure 5. High power examination, original magnifcation $\mathrm{x} 40$. CD30 for the tumour cell are negative.

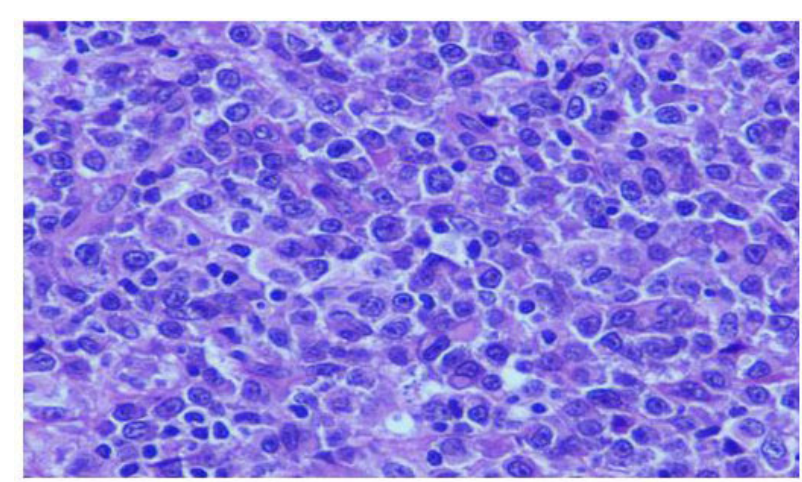

Figure 6. High power examination, original magnifcation $\mathrm{x} 40$. Morphologic features of ALK-positive large B-cell lymphoma. Characteristic plasmablastic and immunoblastic morphology (H\&E staining). 


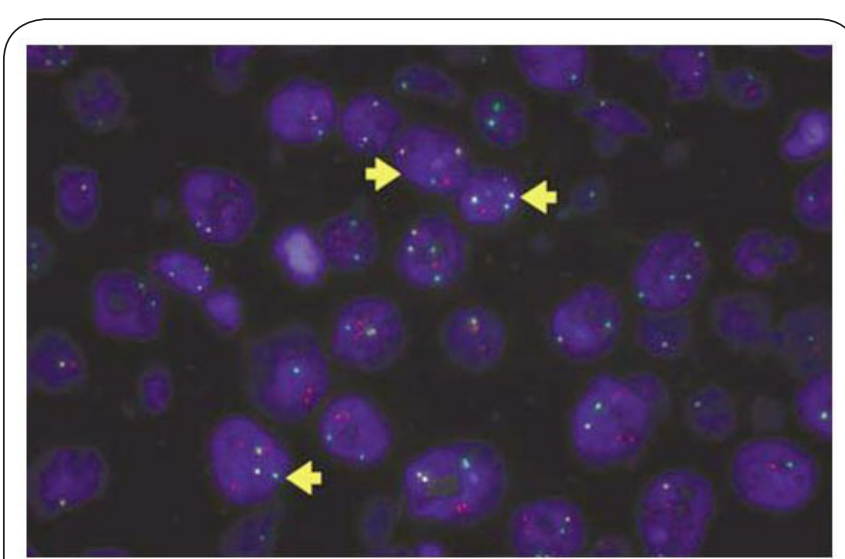

Figure 7. Fluorescence in situ hybridization (FISH) of ALKDLBCL Showing ALK gene rearrangement using the ALK break Apart probe from Vysi Inc. The FISH pattern is positive for rearrangement involving the ALK gene locus (arrows). The typical abnormal pattern would be expected to show $1 \mathrm{R} 1 \mathrm{G} 1 \mathrm{~F}$ (one red and one green signal (abnormal) and one fused (yellow) (the remaining normal allele)). In this particular case, the majority of neoplastic cells also demonstrate an additional fused (yellow), signal indicating either a duplication of the ALK gene region or an additional copy of chromosome 2 .

morphologic and immunophenotypic similarity to those previously described [1-6]. ALK-DLBCL was initially described by [1]. Our study of cases brings the total number of 33 reported cases of ALK-DLBCL in the literature to 34.

ALK-DLBCL has a distinct morphologic appearance with immunoblastic/plasmablastic cytology with round, centrally to eccentrically located nuclei, prominent single central nucleoli, and moderate amounts of variably eosinophilic cytoplasm A sinusoidal growth pattern may be seen Immunohistochemically, ALK-DLBCL shows features suggesting plasmacytic differentiation, with positivity for CD138, VS38c, and monotypic cytoplasmic light chain. The characteristic ALK staining is usually cytoplasmic and coarsely granular Occasional cases with nuclear and cytoplasmic positivity have also been reported. CD4, and CD43 are variably positive, while CD30, B-cell related antigens (CD20), and T-cell related antigens (CD3) are negative.

Although, a fairly typical immunohistochemical (plasmacytic) profile has been established for ALK-DLBCL, it is clear that some immunophenotypic heterogeneity exists. As in some reported case in the review literature.

CD 20 highlighted rare positive tumor cells, providing a helpful clue to the underlying B cell lineage. CD20 positivity, even focal, is distinctly unusual. Also some cases been reported to show scattered cytokeratin (AE1/AE3)-positive tumor cells, which in conjunction with EMA positivity may lead to an erroneous interpretation of carcinoma. In addition, although usually negative [3], report one of their cases as being CD30 positive. The overall morphologic and immunohistochemical features should allow for distinction of ALK-DLBCL from other entities including $\mathrm{ALCL}$, plasmablastic lymphoma, plasmablastic myeloma, anaplastic variant of diffuse large B-cell lymphoma, and carcinoma. ALCL is typically CD30 $(+)$, of T-cell phenotype and would be negative for plasma cell markers (CD138) and immunoglobulin light chain. Plasmablastic lymphomas often occur in the oral region of human immunodeficiency virus-infected individuals, and are EBER positive and ALK negative [15]. The anaplastic variant of DLBCL is usually strong CD20 (+) and ALK (-). Plasmablastic myeloma has not been reported to be ALK positive, and would be associated with other features such as lytic bone lesions and a monoclonal protein in serum and/or urine.The clinical features from the 33 reported cases of ALK-DLBCL are all summarized in. ALK-DLBCL (Table 1 ) spans age groups with an overall male predominance ( $\mathrm{M}: \mathrm{F}$ ratio of $3: 1)$. The $\mathrm{M}: \mathrm{F}$ ratio is similar in children (7:3) and adults (18:5). Commonly reported clinical features included lymphadenopathy (27 cases), hepato- and/or splenomegaly (four cases), bony/CNS extension (four cases), mediastinal mass (four cases), and laryngeal/oral mass (three cases). Although only 33 cases of ALK-DLBCL have been reported thus far, higher stage disease at presentation (III-IV) appears to correlate with a poor Response to multi-agent lymphoma Chemotherapy and an aggressive Clinical course. The overall median survival of high stage III/IV patients $(N=13)$ was 11 months. Of the 11 patients reported as low stage I/II with at least 14 months follow-up, the average disease-free survival was 41 months $(\mathrm{N}=10)$. Only one was dead of disease after 14 months. The recent discovery of underlying ALK rearrangement in ALK-DLBCL.

Is an important advance in our understanding of the pathogenesis of this lymphoma [2-6]. The ALK gene located on chromosome 2p23 may be translocated to either the Clathrin (LCTC) gene on chromosome 5q35, resulting in CLTC-ALK and NPM-ALK fusion products, respectively [2-6,8-11]. Both of these rearrangements were originally identified in classic ALK (+) ALCL, with NPM-ALK being distinctly more common (70-80\% of cases). 16 As in ALCL, the ALK staining pattern in ALK-DLBCL appears to correlate with the type of underlying rearrangement. Cases with CLTC-ALK/t $(2 ; 17)$ rearrangement show a dinstinctly cytoplasmic and granular ALK staining pattern. Whereas those cases with an NPM-ALK/t $(2 ; 5)$ rearrangement show both cytoplasmic and nuclear staining $[2-6,8-11,16]$. However, this correlation may be imperfect, as [5], reported on case of ALK-DLBCL with NPM-ALK fusion that showed cytoplasmic ALK staining only. Thus, ALK gene rearrangements, originally thought to be uniquely associated with $\mathrm{T}-$ /null cell $A L C L$, have now been convincingly shown to occur in rare cases of B-cell lymphoma [2-13]. Of note, prior to the initial series by $[1,17]$ in 1996 reported NPM/ALK fusion transcripts (by RT PCR) in four of 33 cases of large B-cell lymphoma. Interestingly, and in contrast to the cases of ALKDLBCL reported thus far, this case had a conventional B-cell immunophenotype (CD97+). Was EMA (-) and CD30 negative result. ALK aberrations, specifically involving rearrangements 
Nemenqani et al. Pathology Discovery 2013,

http://www.hoajonline.com/journals/pdf/2052-7896-1-8.pdf

doi: $10.7243 / 2052-7896-1-8$

Table 1. Comparison of selected clinical features of the 33 reported cases of ALK-DLBCL.

\begin{tabular}{|c|c|c|c|c|c|c|}
\hline $\begin{array}{l}\text { Author } \\
\text { (Reference) }\end{array}$ & $\begin{array}{c}\text { Case } \\
\text { Number }\end{array}$ & Age \& Sex & Site of the disease & Stage & Therapy & Present clinical status \\
\hline \multirow[t]{7}{*}{ Delsol [1] } & 1 & $53 / \mathrm{M}$ & Systemic LA, splenomegaly & IVA & CTX plus relapsed, BMT & Dead of disease after $26 \mathrm{M}$ \\
\hline & 2 & $15 / \mathrm{M}$ & NR & I & COPAD-Ara-C & Alive without disease after $156 \mathrm{M}$ \\
\hline & 3 & $37 / \mathrm{M}$ & Mediastinal LA (2) & II (I) & M-BACOD (2) & $\begin{array}{l}\text { Cases } 3,4,7 \text { - dead of disease } \\
\text { after } 9 \mathrm{M}\end{array}$ \\
\hline & 4 & $44 / \mathrm{M}$ & -- & III-IV & $\mathrm{B}-\mathrm{CHOP}(1)$ & -- \\
\hline & 5 & $67 / \mathrm{M}$ & -- & (4) & MOPP + XRT (1) & Lost to follow-up after $11 \mathrm{M}$ \\
\hline & 6 & $51 / \mathrm{M}$ & -- & -- & $\operatorname{ACVBP}(2)$ & Alive without disease after $14 \mathrm{M}$ \\
\hline & 7 & $60 / \mathrm{M}$ & -- & -- & -- & See case 3 \\
\hline \multirow[t]{6}{*}{ Gascoyne [2] } & 1 & $46 / \mathrm{M}$ & Supraclavicular and abdominal LA & III & $\begin{array}{l}\text { CTX, relapse at } 5 \text { months, CTX } \\
\text { and XRT }\end{array}$ & -- \\
\hline & 2 & $45 / \mathrm{F}$ & Inguinal tumor & NA & NA & NA \\
\hline & 3 & $49 / \mathrm{M}$ & Systemic LA, epidural mass & IV & CHOP and XRT, partial response & $\begin{array}{l}\text { Alive with progressive disease } \\
\text { after } 9 \mathrm{M}\end{array}$ \\
\hline & 4 & $48 / \mathrm{M}$ & Axillary LA & $1 \mathrm{~A}$ & CTX & Alive without disease after $27 \mathrm{M}$ \\
\hline & 5 & $53 / \mathrm{M}$ & -- & -- & -- & -- \\
\hline & 6 & $58 / \mathrm{M}$ & $\begin{array}{l}\text { Supraclavicular involvement and- } \\
\text { Subarachnoid involvement }\end{array}$ & IV & $\mathrm{CHOP}+$ Rittuximab & Dead of disease after 6 months \\
\hline \multirow[t]{3}{*}{ De Paepe [3] } & 1 & $10 / \mathrm{M}$ & Cervical mass & II & ALCL-99 HR followed by SFOP- & Alive without disease after $6 \mathrm{M}$ \\
\hline & 2 & $13 / \mathrm{F}$ & $\begin{array}{l}\text { Cervical LA, HSM, mediastinal } \\
\text { Mass (at relapse) }\end{array}$ & III & $\begin{array}{l}\text { NHL-BFM ALCL99 with ALCL } \\
\text { relapse, BMT }\end{array}$ & Dead of disease after $3 \mathrm{M}$ \\
\hline & 3 & $26 / \mathrm{M}$ & Cervical LA, base of tongueTumor & II & CHOP_4/vim_1/DHAP & Dead of disease after $14 \mathrm{M}$ \\
\hline Chikatsu [4] & 1 & $36 / \mathrm{F}$ & $\begin{array}{l}\text { Multiple transmuscular tumors, } \\
\text { Bilateral ovarian tumors, HSM }\end{array}$ & IV & Combination CTX & Dead of disease after $11 \mathrm{M}$ \\
\hline \multirow[t]{2}{*}{ Onciu [5] } & 1 & $16 / \mathrm{M}$ & $\begin{array}{l}\text { Scalp and parietal bone mass, } \\
\text { Cervical , axillary, and inguinal LA, } \\
\text { multiple lytic skeletal lesions }\end{array}$ & IV & LMB 89, poor response & Dead of disease after $24 \mathrm{M}$ \\
\hline & 2 & $10 / \mathrm{M}$ & $\begin{array}{l}\text { Laryngeal supraglottic mass, } \\
\text { Cervical and submandibular LA }\end{array}$ & II & POG8719, XRT and DAHP & Alive without disease after $156 \mathrm{M}$ \\
\hline Adam $[6]$ & 1 & $35 / \mathrm{M}$ & $\begin{array}{l}\text { Right cervical and supraclavicular } \\
\text { LA }\end{array}$ & IIA & CHOEP- & Dead of disease after $14 \mathrm{M}$ \\
\hline McManus [7] & 1 & $21 / \mathrm{M}$ & Pyloric mass & IIE & CHOP & Alive without disease after $2 \mathrm{Y}$ \\
\hline Colomo $[8]$ & 1 & $34 / \mathrm{M}$ & Generalized LA & NR & Specialized NR & Dead of disease after $8 \mathrm{M}$ \\
\hline $\begin{array}{l}\text { Ishii [9] } \\
\text { (Abstract only) }\end{array}$ & 1 & $33 / \mathrm{M}$ & $\begin{array}{l}\text { Right neck LA, at relapse multiple } \\
\text { paraaortic LA, and splenomegaly }\end{array}$ & NR & $\begin{array}{l}\text { CR with chemotherapy and local } \\
\text { XRT }\end{array}$ & Dead of disease $31 \mathrm{M}$ \\
\hline \multirow{2}{*}{$\begin{array}{l}\text { Rudzski }[10] \\
\text { abstract }\end{array}$} & 1 & $48 / \mathrm{M}$ & Large upper neck mass & IIIB & CHOP & Dead of disease $3 \mathrm{M}$ \\
\hline & 2 & $49 / \mathrm{M}$ & Abdominal LA, stomach infiltrate & IVB & On chemotherapy & Currently alive \\
\hline \multirow[t]{3}{*}{ Gesk [11] } & 1 & $13 / \mathrm{M}$ & Cervical LA & II & ALCL99 SR: multi-agent CTX & Partial remission \\
\hline & 2 & $12 / \mathrm{F}$ & Mediastinal mass, cervical La & II & Multi-agent chemotherapy & Alive without disease at $4 \mathrm{Y}$ \\
\hline & 3 & $16 / \mathrm{M}$ & $\begin{array}{l}\text { Mediastinal mass, cervical LN, } \\
\text { chest wall and left pleura involved }\end{array}$ & IV & Multi-agent chemotherapy, BMT & Dead of disease after $1 \mathrm{Y}$ \\
\hline Isimbaldi [12] & 1 & $9 / \mathrm{F}$ & Left cervical mass & I & I AIEOP LNH 97, CR, ICE & Dead of disease after $9 \mathrm{M}$ \\
\hline \multirow[t]{5}{*}{ Bubala [13] } & 1 & $9 / \mathrm{M}$ & Ollier disease, generalized LA & III & Multi-agent chemotherapy & Dead of disease after $5 \mathrm{M}$ \\
\hline & 2 & $41 / \mathrm{F}$ & Cervical lymph node & I & CHOP and left neck XRT & Alive without disease at $58 \mathrm{M}$ \\
\hline & 3 & $49 / \mathrm{F}$ & Cervical LA & I & CHOP and left neck XRT & Alive without disease at $36 \mathrm{M}$ \\
\hline & 4 & $71 / \mathrm{M}$ & Nasopharyngeal mass & $\mathrm{I}$ & CHOP and left neck XRT & Dead after $22 \mathrm{M}$ \\
\hline & 5 & $53 / \mathrm{M}$ & Left cervix LA & I & Multi-agent chemotherapy & Currently alive \\
\hline
\end{tabular}


Nemenqani et al. Pathology Discovery 2013,

of the CLTC gene, have also been identified in some cases of inflammatory myofibroblastic tumors (IMT) [18]. Thus, ALK over expression likely contributes to the pathogenesis of a Variety of otherwise unrelated neoplasms, ALK-DLBCL, ALCL, and IMT.

\section{Competing interests}

The authors declare that they have no competing interests.

Authors' contributions

\begin{tabular}{|l|c|c|c|c|c|c|c|}
\hline Authors' contributions & EMJ & DMN & JMJ & AAS & SMA & AMM & HB \\
\hline Research concept and design & $\checkmark$ & $\checkmark$ & -- & $\checkmark$ & -- & -- & -- \\
\hline $\begin{array}{l}\text { Collection and/or assembly } \\
\text { of data }\end{array}$ & $\checkmark$ & $\checkmark$ & -- & $\checkmark$ & -- & -- & -- \\
\hline $\begin{array}{l}\text { Data analysis and } \\
\text { interpretation }\end{array}$ & $\checkmark$ & $\checkmark$ & -- & -- & -- & -- & -- \\
\hline Writing the article & $\checkmark$ & -- & -- & -- & -- & -- & - \\
\hline Critical revision of the article & $\checkmark$ & $\checkmark$ & $\checkmark$ & -- & $\checkmark$ & -- & $\checkmark$ \\
\hline Final approval of article & $\checkmark$ & $\checkmark$ & $\checkmark$ & -- & $\checkmark$ & $\checkmark$ & $\checkmark$ \\
\hline Statistical analysis & $\checkmark$ & $\checkmark$ & -- & -- & -- & -- & - \\
\hline
\end{tabular}

\section{Publication history}

Editor: Takuji Tanaka, Gifu University, Japan.

Received: 20-Oct-2013 Revised: 23-Nov-2013

Re-Revised: 02-Dec-2013 Accepted: 08-Dec-2013

Published: 20-Dec-2013

\section{References}

1. Delsol G, Lamant L, Mariame B, Pulford K, Dastugue N, Brousset P, RigalHuguet F, al Saati T, Cerretti DP, Morris SW and Mason DY. A new subtype of large B-cell lymphoma expressing the ALK kinase and lacking the 2; 5 translocation. Blood. 1997; 89:1483-90. | Article | PubMed

2. Gascoyne RD, Lamant L, Martin-Subero JI, Lestou VS, Harris NL, MullerHermelink HK, Seymour JF, Campbell LJ, Horsman DE, Auvigne I, Espinos $E$, Siebert $R$ and Delsol G. ALK-positive diffuse large B-cell lymphoma is associated with Clathrin-ALK rearrangements: report of 6 cases. Blood. 2003; 102:2568-73. | Article | PubMed

3. De Paepe $P$, Baens $M$, van Krieken $H$, Verhasselt $B$, Stul M, Simons $A$, Poppe B, Laureys G, Brons $P$, Vandenberghe $P$, Speleman F, Praet $M$, De Wolf-Peeters C, Marynen P and Wlodarska I. ALK activation by the CLTCALK fusion is a recurrent event in large B-cell lymphoma. Blood. 2003; 102:2638-41. | Article | PubMed

4. Chikatsu N, Kojima H, Suzukawa K, Shinagawa A, Nagasawa T, Ozawa H, Yamashita Y and Mori N. ALK+, CD30-, CD20- large B-cell lymphoma containing anaplastic lymphoma kinase (ALK) fused to clathrin heavy chain gene (CLTC). Mod Pathol. 2003; 16:828-32. | Article | PubMed

5. Onciu M, Behm FG, Downing JR, Shurtleff SA, Raimondi SC, Ma Z, Morris SW, Kennedy W, Jones SC and Sandlund JT. ALK-positive plasmablastic B-cell lymphoma with expression of the NPM-ALK fusion transcript: report of 2 cases. Blood. 2003; 102:2642-4. | Article | PubMed

6. Adam $P$, Katzenberger $T$, Seeberger $H$, Gattenlohner $S$, Wolf J, Steinlein C, Schmid M, Muller-Hermelink HK and Ott G. A case of a diffuse large B-cell lymphoma of plasmablastic type associated with the $t(2 ; 5)$ (p23;q35) chromosome translocation. Am J Surg Pathol. 2003; 27:14736. | Article | PubMed

7. McManus DT, Catherwood MA, Carey PD, Cuthbert RJ and Alexander HD. ALK-positive diffuse large B-cell lymphoma of the stomach associated with a clathrin-ALK rearrangement. Hum Pathol. 2004; 35:1285-8. Article | PubMed

8. Colomo L, Loong F, Rives S, Pittaluga S, Martinez A, Lopez-Guillermo A, Ojanguren J, Romagosa V, Jaffe ES and Campo E. Diffuse large B-cell lymphomas with plasmablastic differentiation represent a heterogeneous group of disease entities. Am J Surg Pathol. 2004; 28:736-47. | Article | PubMed

9. Ishii K, Yamamoto $Y$ and Nomura S. CD30-negative diffuse large B-cell lymphoma expressing ALK. Rinsho Ketsueki. 2005; 46:501-6. | Article | PubMed

10. Rudzki Z, Rucinska M, Jurczak W, Skotnicki AB, Maramorosz-Kurianowicz M, Mruk A, Pirog K, Utych G, Bodzioch P, Srebro-Stariczyk M, Wlodarska $I$ and Stachura J. ALK-positive diffuse large B-cell lymphoma: two more cases and a brief literature review. Pol J Pathol. 2005; 56:37-45. | Pdf | PubMed

11. Gesk S, Gascoyne RD, Schnitzer B, Bakshi N, Janssen D, Klapper W, Martin-Subero JI, Parwaresch R and Siebert R. ALK-positive diffuse large B-cell lymphoma with ALK-Clathrin fusion belongs to the spectrum of pediatric lymphomas. Leukemia. 2005; 19:1839-40. | Article | PubMed

12. Isimbaldi G, Bandiera L, d'Amore ES, Conter V, Milani M, Mussolin L and Rosolen A. ALK-positive plasmablastic B-cell lymphoma with the clathrin-ALK gene rearrangement. Pediatr Blood Cancer. 2006; 46:3901. | Article | PubMed

13. Bubala H, Maldyk J, Wlodarska I, Sonta-Jakimczyk D and Szczepanski T. ALK-positive diffuse large B-cell lymphoma. Pediatr Blood Cancer. 2006; 46:649-53. | Article | PubMed

14. Reichard KK, McKenna RW and Kroft SH. Comparative analysis of light chain expression in germinal center cells and mantle cells of reactive lymphoid tissues. A four-color flow cytometric study. Am J Clin Pathol. 2003; 119:130-6. | Article | PubMed

15. Vega F, Chang CC, Medeiros LJ, Udden MM, Cho-Vega JH, Lau CC, Finch $\mathrm{CJ}$, Vilchez RA, McGregor D and Jorgensen JL. Plasmablastic lymphomas and plasmablastic plasma cell myelomas have nearly identical immunophenotypic profiles. Mod Pathol. 2005; 18:806-15. | Article | PubMed

16. Gatter KC and Warnke RA. Diffuse large B-cell lymphoma. In: Jaffe ES, Harris NL, Stein H, Vardiman JW (eds). World Health Organization Classification of Tumors: Tumors of the Haematopoietic and Lymphoid Tissues. IARC: Lyon, France, 2001; 174.

17. Arber DA, Sun LH and Weiss LM. Detection of the $t(2 ; 5)(p 23 ; q 35)$ chromosomal translocation in large B-cell lymphomas other than anaplastic large cell lymphoma. Hum Pathol. 1996; 27:590-4. | Article | PubMed

18. Bridge JA, Kanamori M, Ma Z, Pickering D, Hill DA, Lydiatt W, Lui MY, Colleoni GW, Antonescu CR, Ladanyi M and Morris SW. Fusion of the ALK gene to the clathrin heavy chain gene, CLTC, in inflammatory myofibroblastic tumor. Am J Pathol. 2001; 159:411-5. | Article | PubMed Abstract | PubMed Full Text

\section{Citation:}

Nemenqani D, Junainah E, Al-Amoudi S, Junainah J, Mamdouh A, Bajunaid $\mathrm{H}$ and Saber A. ALK positive diffuse large B-cell lymphoma, lymphoplasmablastic differentiation. Pathol Discov. 2013; 1:8. http://dx.doi.org/10.7243/2052-7896-1-8 